\title{
PERANCANGAN PEMBELAJARAN E-LEARNING BAHASA INGGRIS UNTUK PEMULA BERBASIS MULTIMEDIA
}

\author{
Wilda Susanti ${ }^{1}$, Rangga Rahmadian Yuliendi ${ }^{2}$, Ambiyar $^{3}$, Wakhinuddin ${ }^{4}$ \\ ${ }^{1,2}$ Teknik Informatika, Sekolah Tinggi Ilmu Komputer Pelita Indonesia, \\ Jalan A.Yani No. 70 Pekanbaru \\ ${ }^{3,4}$ Universitas Negeri Padang, Jalan Prof. Dr. Hamka, Air Tawar, Kec. Padang Utara, Kota Padang \\ e-mail: wilda@lecturer.pelitaindonesia.ac.id
}

\begin{abstract}
Abstrak
Tujuan penelitian adalah merancang aplikasi pembelajaran e-learning bahasa Inggris berbasis multimedia dengan menggabungkan konsep yang terdiri dari teks, gambar, animasi, dan video. Subjek penelitian adalah siswa SMA kelas X. Dalam mengimplementasikan aplikasi pembelajaran, peneliti menggunakan Moodle. Metode pengembangan sistem menggunakan System Development Live Cycle (SDLC). Untuk analisis dan perancangan sistem menggunakan metode Unified Modelling Language (UML). Peneliti berhasil merancang aplikasi pembelajaran yang dapat dijadikan sebagai media pembelajaran Bahasa Inggris untuk tingkat pemula dengan tema learning by doing. Aplikasi pembelajaran yang dirancang diharapkan dapat membantu meningkatkan proses belajar bahasa Inggris terutama dalam membaca, menghapal, dan mengucapkan kosakata.
\end{abstract}

Kata Kunci: analisis, perancangan, e-learning, multimedia.

\begin{abstract}
The purpose of the research was to design the e-learning of English multimediabased application by combining concepts consisting of text, images, animation, and video. The research subjects were high school students in class X. In implementing the learning application, researchers used Moodle. The system development method uses the System Development Live Cycle (SDLC). For system analysis and design using the Unified Modeling Language (UML) method. Researchers succeeded in designing learning applications that can be used as a medium of learning English for the beginner level with the theme of learning by doing. Learning applications that are designed are expected to help improve the process of learning English, especially in reading, memorizing, and speaking vocabulary.
\end{abstract}

Keywords: analysis, design, e-learning, multimedia.

\section{PENDAHULUAN}

Menguasai bahasa Inggris merupakan suatu keharusan pada era globalisasi. Bahasa Inggris menjadi modal untuk dapat berkomunikasi dengan negara lain, karena bahasa Inggris merupakan bahasa internasional. Seiring Perkembangan teknologi informasi (TI) yang semakin pesat, kebutuhan akan suatu konsep dan mekanisme belajar-mengajar (pendidikan) bahasa Inggris berbasis TI tidak terelakkan. Konsep yang kemudian terkenal dengan sebutan e-learning memberikan pengaruh terjadinya proses tranformasi pendidikan konvensional ke 
dalam bentuk digital, baik secara isi (contents) dan sistemnya. E-learning telah memberikan banyak manfaat diberbagai bidang, sehingga pekerjaan rumit dapat dengan mudah diselesaikan dalam waktu singkat. Pekerjaan yang biasanya sulit dipahami bisa dimengerti dengan adanya e-learning. Sistem pembelajaran elektronik biasanya di singkat menjadi e-learning adalah proses baru dalam proses belajar-mengajar (Ranius, 2013).

Sekolah Menengah Atas (SMA) adalah salah satu jenjang pendidikan menengah pada pendidikan formal yang ada di Indonesia. Pembelajaran bahasa Inggris merupakan salah satu mata pelajaran yang ada di SMA. Bahasa Inggris adalah mata pelajaran wajib yang cukup menguras pikiran yang harus dipahami. Kurangnya pelatihan untuk siswa mengasah kemampuan bahasa Inggris saat di rumah, mengakibatkan kekhawatiran siswa dalam menghadapi ujian akhir sekolah, apalagi jika dengan metode pembelajaran di kelas yang diberikan guru tidak merangsang pola pikir siswa dengan baik, lebih menekankan anak menghapal dan mencatat tanpa tahu dan mengerti bagaimana maknanya.

Strategi atau teknik dalam pembelajaran sangat dibutuhkan oleh seorang pendidik (Susanti dan Ambiyar, 2018). Untuk meningkatkan mutu pendidikan penggunaan media sangat dibutuhkan (Dharmayanti dan Oktarika, 2019). Pemanfaatan media diperlukan guna melengkapai cara konvensional (Kim, et al., 2013). Penggunaan media pembelajaran dalam kegiatan tatap muka ataupun secara tidak langsung dapat membantu proses interaksi antara guru dan siswa. Seiring dengan perkembangan ilmu pengetahuan dan teknologi (IPTEK) media tidak hanya berfungsi sebagai alat bantu/alat peraga tetapi sudah mampu memenuhi kebutuhan siswa. Komputer sebagai salah satu media yang mampu menggantikan memadukan atau menggabungkan media grafis/visual dan media audio berupa multimedia (Ampa, et al., 2013).

Media pembelajaran dengan e-learning dengan memanfaatkan multimedia dalam pemberian materi salah satu solusi dalam kesulitan pembelajaran bahasa Inggris (Muslem and Abbas, 2017). Metode pembelajaran mulitmedia lebih menitikberatkan pada aktivitas siswa, sedangkan guru hanya bertindak sebagai fasilitator. Pembelajaran dengan multimedia untuk pembelajaran bahasa Inggris 
sangat menarik untuk dikembangkan. Hal tersebut didukung oleh kelebihankelebihan dari pembelajaran multimedia dibandingkan dengan metode tatap muka (Arpan dan Sadikin, 2020). Salah satu kelebihan utamanya adalah pada visualisasi dari permasalahan nyata, sehingga dapat meningkatkan daya ingat dan pemahaman siswa dalam menyimpan materi pelajaran dalam waktu yang lebih lama sehingga terbukti efektif dalam mengembangkan keterampilan kelancaran berbahasa Inggris (Diyyab, 2014).

Pengembangan teknologi multimedia dalam mengajar bahasa Inggris membuat kelas lebih aktif dibandingkan dengan model yang berpusat pada guru (Brett, 1995). Multimedia interaktif memenuhi tuntutan pembelajaran di era digital (Gilakjani, 2012). Beberapa faktor yang dapat mempengaruhi belajar siswa adalah minat/ketertarikan siswa dan motivasi belajar siswa. Dalam proses belajar, siswa harus memiliki minat dalam mengikuti kegiatan dalam belajar, tapi kenyataannya sebanyak 32 siswa atau sebesar 23,4\% siswa tidak lulus kriteria kelulusan mininal (KKM) untuk pelajaran bahasa Inggris. Guru dalam proses pembelajaran lebih mendominasi dan lebih memberikan bekal berupa teori dari pada mengutamakan keterampilan berbahasa baik lisan maupun tulisan (Komalasari, 2019). Untuk meningkatkan minat belajar siswa, maka dibuat suatu aplikasi multimedia sebagai media pembelajaran.

Hasil observasi dan wawancara diketahui bahwa kesulitan siswa kelas X tingkat pemula untuk memahami pembelajaran bahasa Inggris adalah guru belum menggunakan media yang dapat berinteraksi ke siswa secara langsung dengan konsep e-learning, sehingga konsep learning by doing belum dapat dilakukan. Padahal media pembelajaran yang dirancang secara baik dengan memanfaatkan teknologi informasi sudah merupakan suatu keharusan (Muhson, 2010). Berdasarkan permasalahan yang telah diuraikan tersebut, maka tujuan penelitian adalah untuk merancang aplikasi pembelajaran e-learning bahasa Inggris berbasis multimedia dengan menggabungkan konsep yang terdiri dari teks, gambar, animasi, dan video. 


\section{METODE}

Metode penelitian yang digunakan adalah System Development Life Cycle (SDLC). Langkah-langkah SDLC terlihat pada Gambar 1 (Nugroho, 2010).

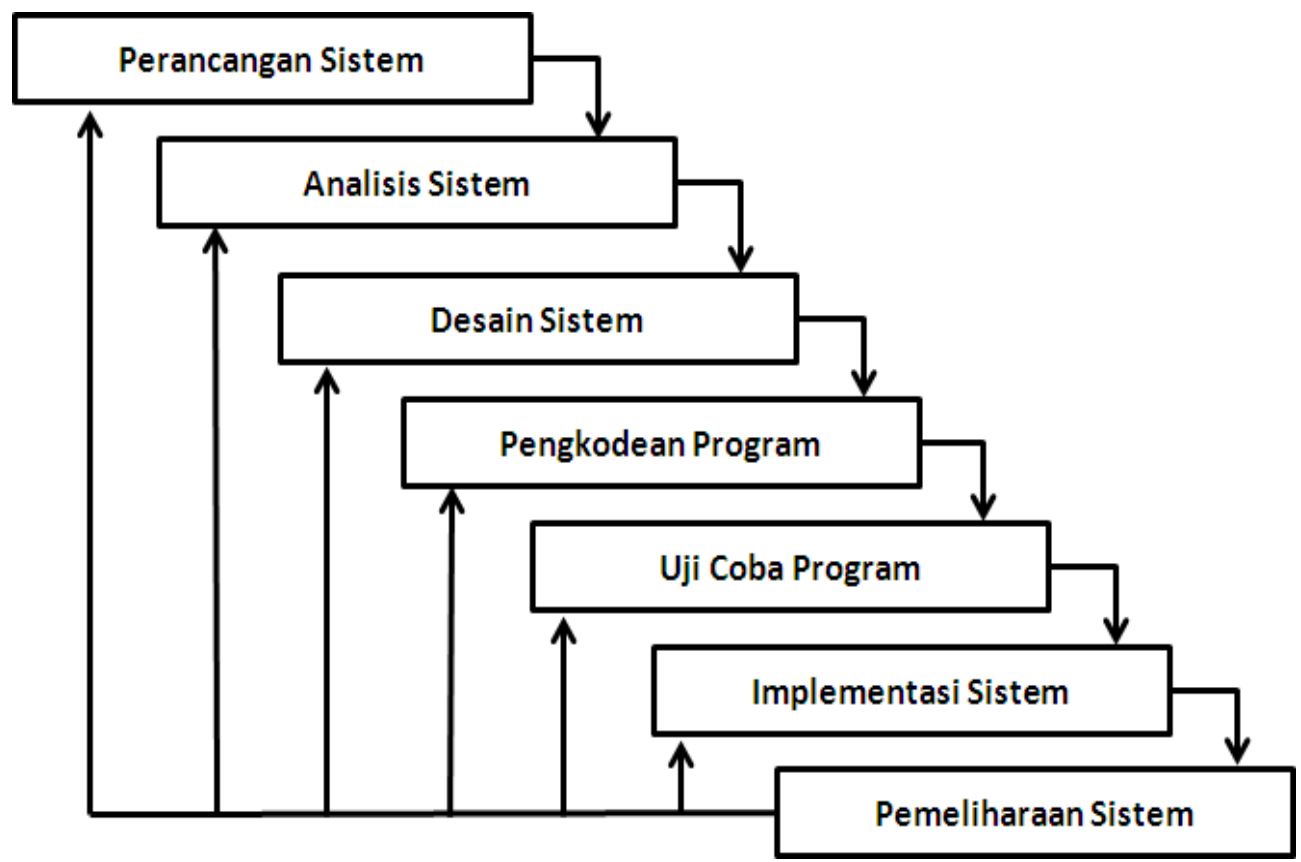

Gambar 1 Tahap Pengembangan SDLC

Penelitian yang dilakukan sampai pada tahap Pengkodean Program. Berikut adalah langkah-langkah yang dilakukan peneliti. Perancangan system adalah langkah awal yang dilakukan dalam penelitian dengan memantau, menjabarkan, dan menyimpulkan kegiatan sistem informasi yang sedang digunakan. Hal yang dilakukan peneliti untuk mengetahui penerapan sistem informasi yang digunakan yaitu wawancara ke siswa dan guru.

Analisis sistem adalah penguraian dari suatu sistem yang utuh kedalam kegiatan-kegiatan komponennya, dengan maksud untuk mengidentifikasikan dan mengevaluasi permasalahan-permasalahan, kesempatan-kesempatan, hambatanhambatan, yang terjadi dan kebutuhan-kebutuhan yang diharapkan sehingga dapat diusulkan perbaikan-perbaikannya. Pada tahap analisis sistem, langkah pertama yang harus dilakukan adalah melakukan identifikasi terlebih dahulu masalahmasalah yang terjadi. Mengindentikasi masalah dimulai dengan mengkaji subjek permasalahan yang ada. Adapun permasalahan yang ada pembelajaran bahasa Inggris untuk tingkat pemula adalah pembelajaran masih berpusat pada guru, 
pembelajaran masih kurang menarik. Hal tersebut menyebabkan siswa merasa malu dan takut apabila terjadi kesalahan ucapan, karena takut ada yang mencela. Dari permasalahan yang terjadi, peneliti mengidentifikasi penyebab terjadi masalah, yaitu belum adanya suatu media pembelajaran yang menarik yang dapat memberikan kemudahan siswa dalam belajar bahasa Inggris.

Desain sistem adalah persiapan rancang bangun implementasi yang menggambarkan bagaimana suatu sistem dibentuk yang penggambaran, perencanaan dan pembuatan sketsa atau pengaturan dari beberapa elemen yang terpisah kedalam satu kesatuan yang utuh dan berfungsi, menyangkut didalamnya konfigurasi komponen perangkat lunak dan perangkat keras dari suatu sistem. Desain model yang digunakan adalah model logika yang lebih menjelaskan kepada user bagaimana nantinya fungsi-fungsi sistem informasi secara logika akan bekerja. Desain antarmuka adalah tahap yang harus dilakukan sebelum mulai membuat multimedia. Konsep rancangan dalam mendesain multimedia adalah tampilan pada komputer yang akan diakses oleh pengguna.

Output adalah keluaran yang dihasilkan oleh sistem yang dirancang berupa aplikasi berbasis multimedia. Desain input ditentukan dari use case diagram sistem baru yang telah dibuat, selanjutnya ditentukan parameternya, seperti bentuk dari input dan dokumen dasar atau bentuk isian di dialog layar. Desain kontrol bertujuan untuk mencegah atau menjaga terjadinya hal-hal yang tidak diinginkan seperti kesalahan-kesalahan dan kecurangan-kecurangan untuk melindungi sistem informasi dari hal-hal yang merugikan. Pengendalian dalam sistem informasi yang dilakukan adalah pengendalian aplikasi, yaitu pengendalian yang diterapkan selama proses pengolahan data berlangsung yang meliputi pengendalian masukan, pengolahan dan keluaran. Desain teknologi yang diterapkan pada siswa tingkat pemula adalah pembuatan e-learning berbasis multimedia yang memudahkan user/siswa untuk belajar pembelajaran bahasa Inggris. Menerjemahkan hasil proses perancangan menjadi sebuah bentuk program komputer yang dimengerti oleh komputer.

Uji coba software merupakan elemen yang penting dari Software Quality Assurance (SQA) dan mempresentasikan tinjauan ulang yang menyeluruh 
terhadap spesifikasi, desain, dan pengkodean. Uji coba mempresentasikan ketidaknormalan yang terjadi pada pengembangan software. Selama definisi awal dan fase pengembangan, pengembang berusaha untuk membangun software dari konsep yang abstrak sampai dengan implementasi yang memungkinkan.

Tahap implementasi adalah tahap semua elemen dan aktivitas sistem disatukan dengan langkah-langkah sebagai berikut: Fasilitas-fasilitas fisik yang disiapkan antara lain komputer dan periferalnya, termasuk keamanan fisik untuk menjaga berlangsungnya peralatan dalam jangka waktu yang lama. Subjek penelitian adalah siswa Sekolah Menengah Atas kelas Sepuluh yang akan diterapkan pada semester ganjil tahun ajaran 2020-2021 kelas X IPA 1 dan X IPA 2 pada sekolah SMA Negeri 5 Tapung. Pemakai aplikasi diberikan pelatihan secara prosedural maupun tutorial mengenai sistem informasi sesuai fungsi tugasnya. Tujuannya adalah agar para pemakai mengerti dan mengusai aplikasi dan cara kerja sistem serta apa saja yang diperoleh dari sistem. Dalam proses pengembangan, terdapat 3 alasan perlunya pemeliharaan sistem, yaitu: (1) Untuk membenarkan kesalahan atau kelemahan sistem yang tidak terdeteksi pada saat pengujian; (2) Untuk membuat sistem up to date; dan (3) Untuk meningkatkan kemampuan sistem.

\section{HASIL DAN PEMBAHASAN}

Sebagai langkah awal, untuk merancang sistem informasi baru adalah dengan membuat model menggunakan alat bantu UML. Berikut adalah modelmodel yang dirancang menggunakan UML yang terdiri atas use case diagram untuk menggambarkan interaksi aktor-aktor dengan sistem, serta activity diagram untuk menggambarkan aktivitas sistem secara internal.

\section{Use Case Diagram Baru}

Use case diagram yang menggambarkan interaksi antara aktor utama dengan sistem e-learning yang digambarkan pada simbol elips $(\bigcirc)$. Simbol tersebut adalah kegiatan yang dilakukan oleh aktor utama atau disebut dengan use case. Ada dua aktor utama, yaitu siswa dan admin program. Aktor pertama yaitu 
siswa melakukan enam kegiatan utama, yaitu login, memilih materi, mempelajari materi, mengerjakan soal, mendapatkan nilai, dan melihat grafik penilaian. Sedangkan aktor kedua, yaitu admin program melakukan satu kegiatan utama yaitu update data soal dan materi. Adapun use case login dapat dilaksanakan jika kegiatan pendukungnya sudah dilakukan (<<extend $\rangle>)$ yaitu sign up.

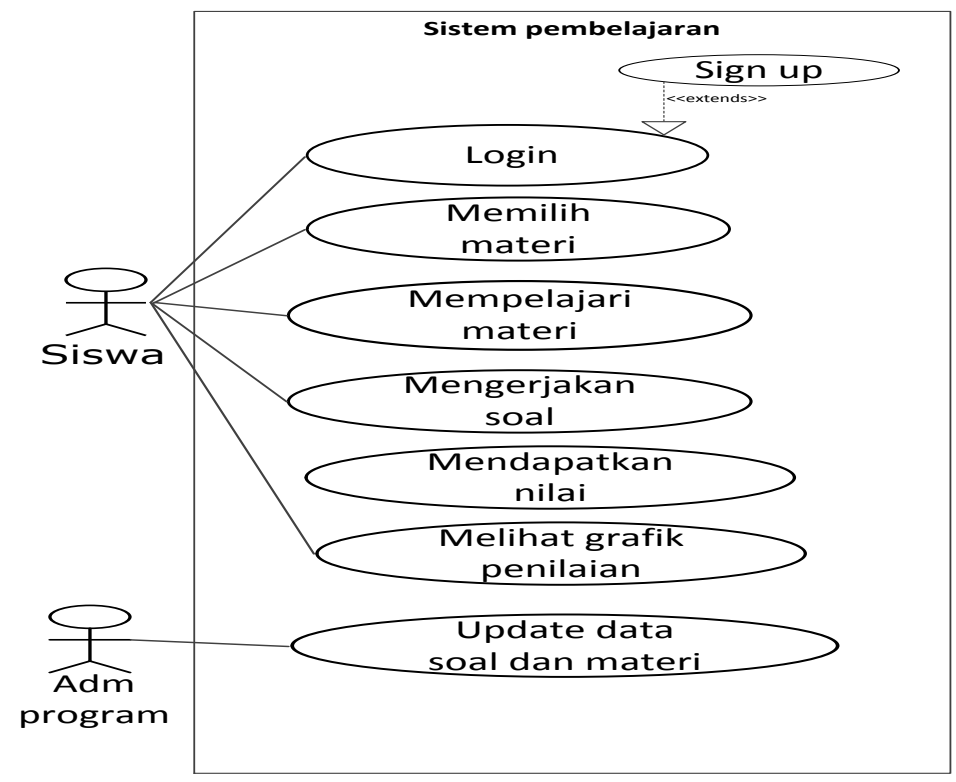

Gambar 1 Use Case Diagram Baru

\section{Activity Diagram Sistem Baru}

Activity diagram baru sesuai aktivitas siswa. Terlihat sebagian aktivitas tersebut berada dalam decision ). Desicion berarti terdapat satu aktivitas yang memiliki percabangan aktivitas lebih dari satu. Activity diagram baru yang terlihat aktivitas diawali dengan simbol start point ( ()). Aktivitas dimulai dari siswa melakukan sing up, kemudianlogin. Jika sudah login siswa memilih materi lalu siswa dapat mempelajarinya. Jika sudah mempelajarinya siswa dapat mengerjakan soal. Setelah siswa mengerjakan soal siswa mendapatkan nilai dan langsung juga dapat melihat grafik penilaian. Urutan aktivitas tersebut diakhiri dengan end point (O). 


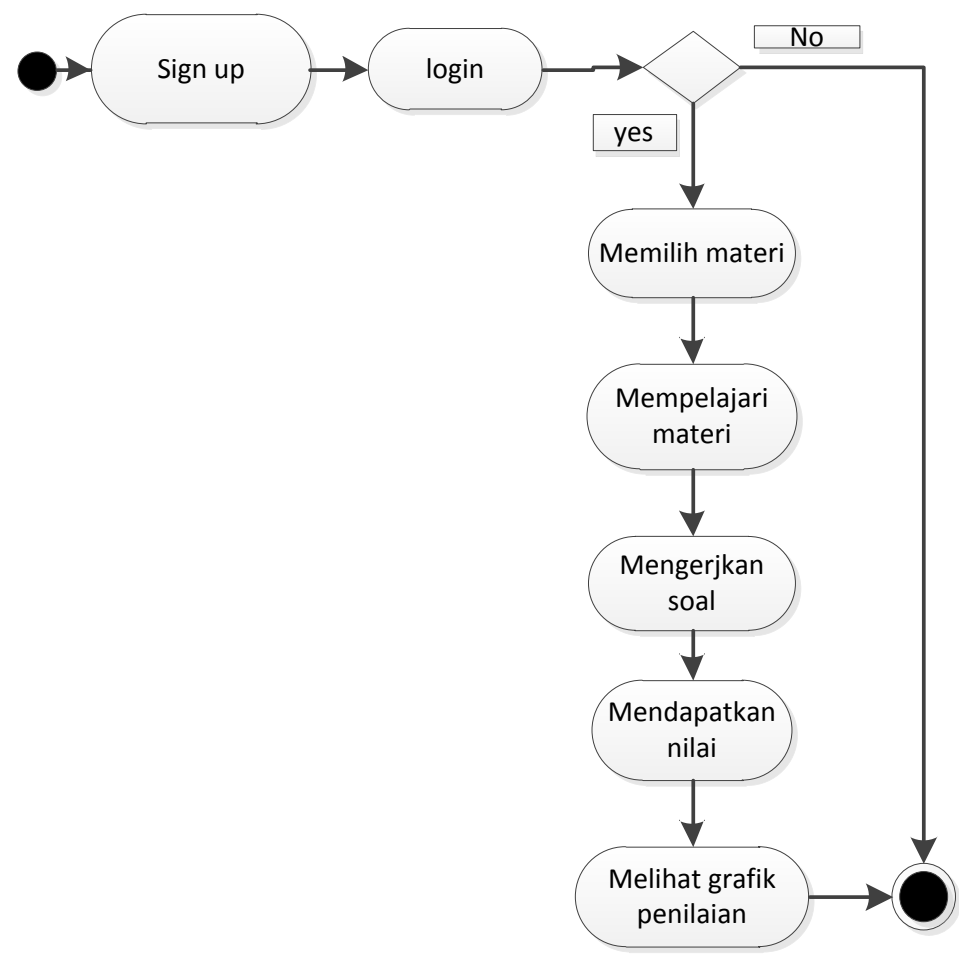

Gambar 2 Activity Diagram Baru

\section{Activity Diagram Secara Keseluruhan Sesuai Aktor Utama Siswa}

Siswa melakukan login dan sistem mencocokan data user, jika tidak cocok sistem membei informasi gagal login dan jika cocok, maka langsung ditampilkan Menu Utama sistem e-learning. Siswa memilih form materi lalu melihat penjelasan materi dan bisa juga memilih mengerjakan soal, jika siswa melihat form penjelasan materi, maka sistem akan menampilkan materi dan siswa dapat mempelajarinya. Jika siswa memilih form mengerjakan soal, maka sistem akan menampilkan soal dan siswa mengerjakannya. Setelah mengerjakann soal, jawaban dimasukkan (input) ke sistem lalu sistem menghitung nilai dan menyimpannya di database lalu menampilkannya dan siswa dapat melihat nilai juga grafik penilaian. Urutan aktivitas tersebut diakhiri dengan end point. 


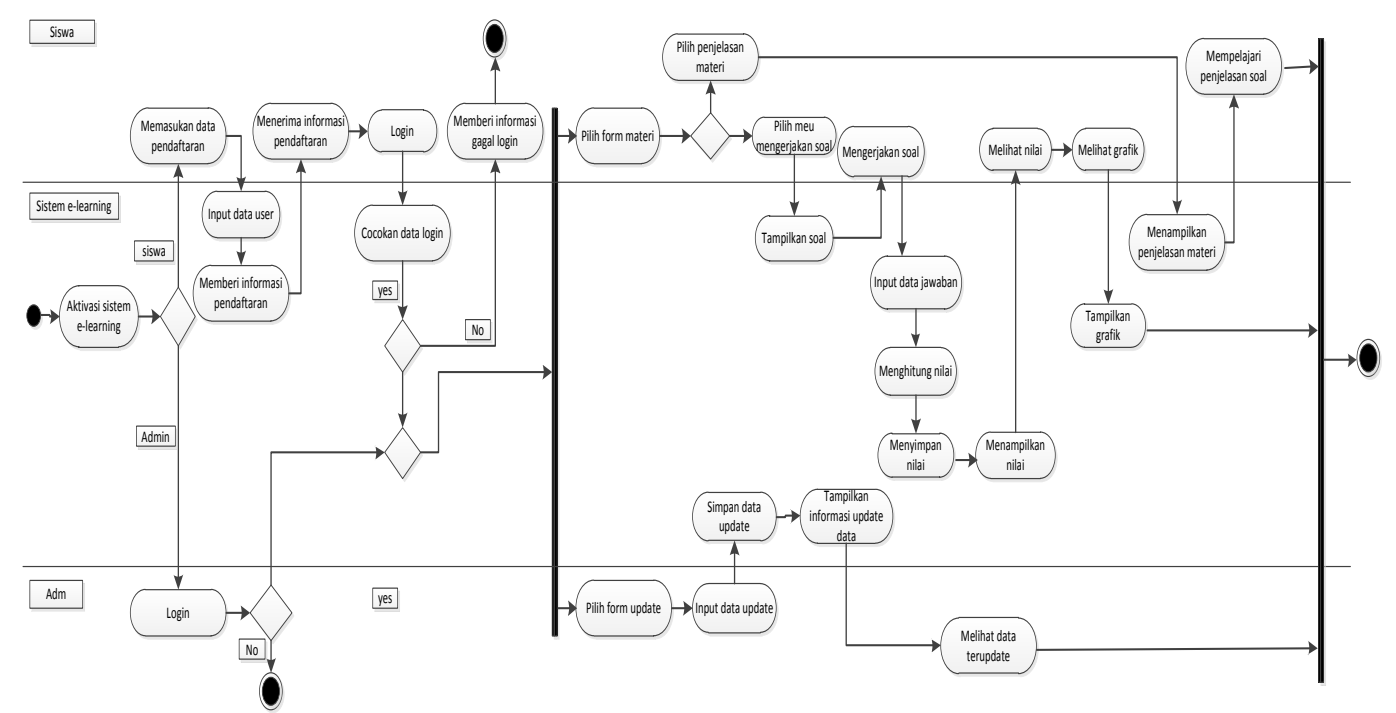

Gambar 3 Activity Diagram Secara Keseluruhan

Hasil perancangan system berupa aplikasi pembelajaran e-learning bahasa Inggris berupa Learning Management System menggunakan Moodle berbasis multimedia. Hasil perancangan aplikasi pembelajaran terlihat pada Tabel 1.

Tabel 1 Aplikasi E-Learning Pembelajaran Bahasa Inggris Berbasis Multimedia

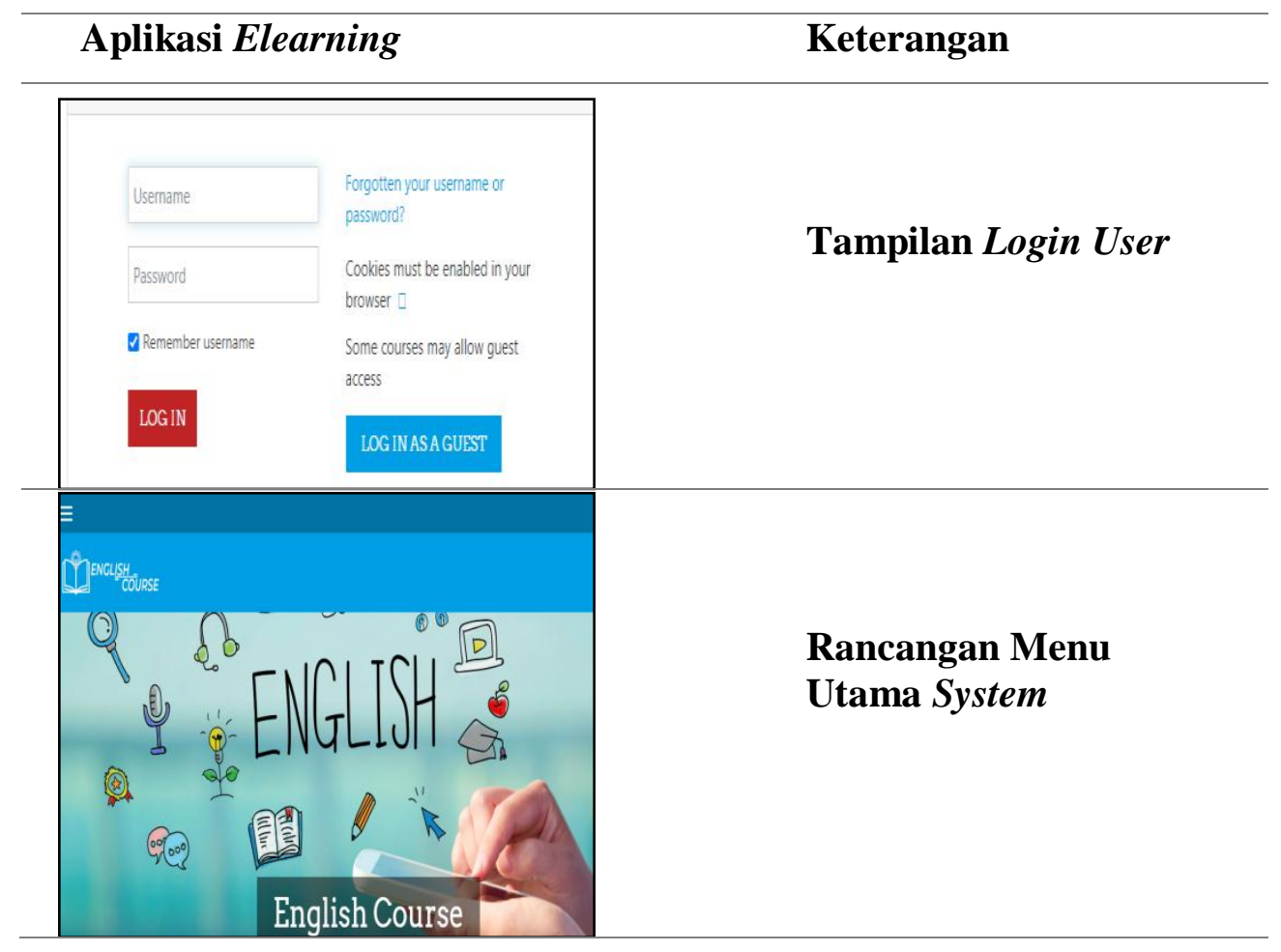



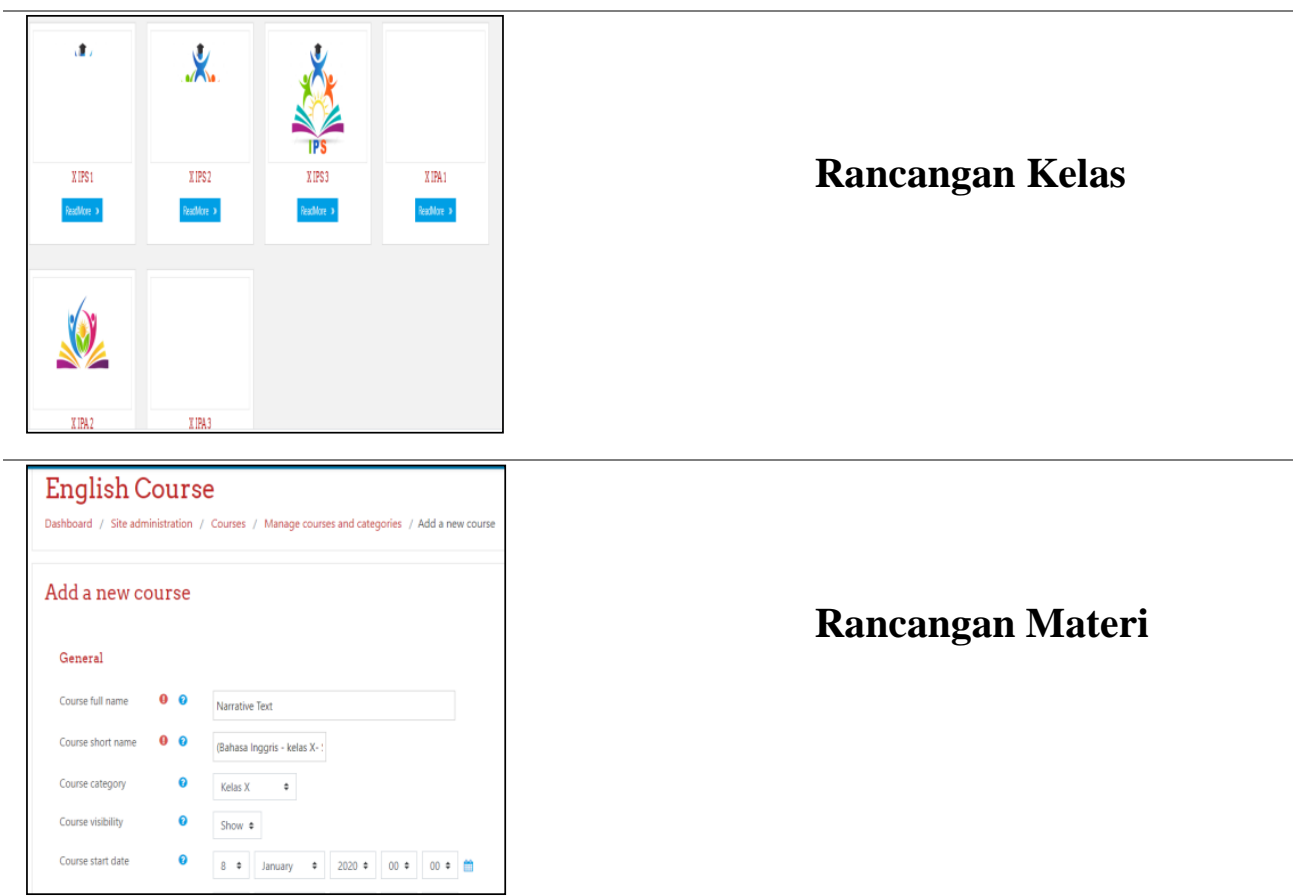

\section{Rancangan Materi}

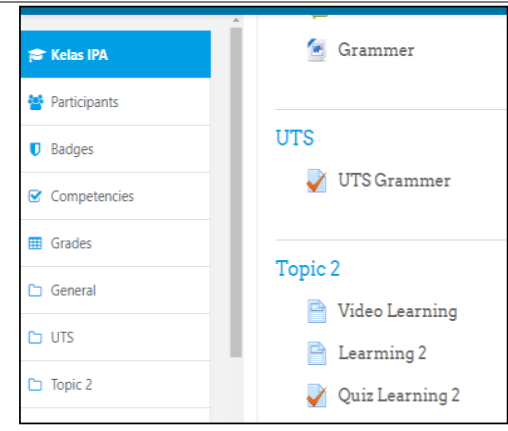

\section{Rancangan Ujian}

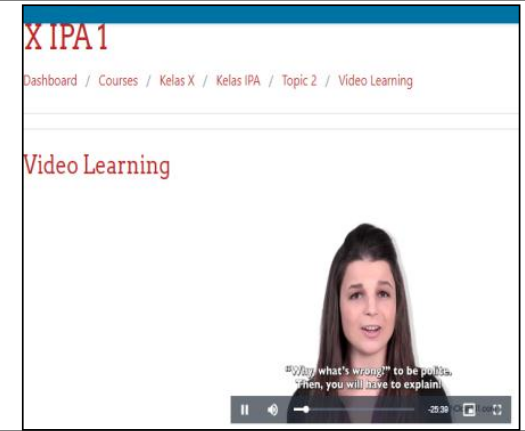

Aplikasi dapat membantu guru dalam menerapkan pembelajaran secara Student Center Learning (SCL) dengan memanfaatkan teknologi informasi (Arpan, dkk., 2020). Ada 2 komponen utama dalam pembelajaran berbasis IT, yaitu Learning Management System dan Learning Content dengan fungsi: (1) Dapat mengelola materi pembelajaran; (2) Melakukan pendaftaran peserta 
pembelajaran; (3) Merekam aktivitas belajar mengajar; (4) Melakukan evaluasi; dan (5) Sebagai media komunikasi (Muhson, 2010). Inovasi pembelajaran berbasis teknologi dapat memberikan peluang untuk mengasah dan memacu kompetensi siswa dan membawa peran penting dalam pendidikan melalui pembelajaran berbasis e-learning (Mulyadi dan Purnama, 2019).

\section{SIMPULAN}

Produk yang dihasilkan dari penelitian ini adalah aplikasi media pembelajaran elearning bahasa inggris berbasis multimedia yang akan diterapkan pada siswa sekolah menengah atas yaitu kelas sepuluh IPA 1 dan IPA 2. Dimana dengan adanya aplikasi ini siswa memiliki penguasaan materi yang cukup, dalam membaca, menghapal dan mengucapkan kosakata dengan konsep learning by doing sehingga tingkat penguasaan siswa dalam proses belajar mengajar dapat ditingkatkan.

\section{UCAPAN TERIMA KASIH}

Penelitian didukung oleh Kementerian Riset, Teknologi, dan Pendidikan Tinggi dengan nomor kontrak B/87/E3/RA.00/2020 dan Sekolah Tinggi Ilmu Komputer Pelita Indonesia Pekanbaru Riau.

\section{DAFTAR PUSTAKA}

Ampa, A. T., Rasyid, M. A., Rahman, M. A., Haryanto, Basri, M. 2013. The Implementation of Multimedia Learning Materials in Teaching English Speaking Skills. International Journal of English Language Education, 1(3): 293-304.

Arpan, M. \& Sadikin. 2020. Media Pembelajaran Interaktif Perangkat Keras Komputer. INVOTEK: Jurnal Inovasi Vokasional dan Teknologi, 20(2): 4350.

Arpan, M., Salaman, Budiman, R. D. A., Ambyar, \& Wakhinudin. 2020. Student Learning Outcomes Using Drill and Practice Type of Computer Assisted Instruction. International Journal of Scientific \& Technology Research, 9(04): 1433-1436.

Brett, P. L. 1995. Multimedia for Listening Comprehension: The Design of A Multimedia-Based Resource for Developing Listening. Elsevier Science, 23(1): 77-85.

Dharmayanti, W. \& Oktarika, D. 2019. Pengembangan Media Pembelajaran 
Berbasis Multimedia Interaktif untuk Guru IPA di Sekolah Menengah Pertama. Jurnal Pendidikan Informatika dan Sains, 8(1): 41-51.

Diyyab, E. A. 2014. Using a Multimedia-Based Program for Developing Student Teachers' EFL Speaking Fluency Skills. Journal of Faculty of Eduction, 25(99): 1-28.

Gilakjani, A. P. 2012. The Significant Role of Multimedia in Motivating EFL Learners Interest in English Language Learning. I.J. Modern Education and Computer Science, 4(5): 57-66.

Kim, D., Kim, D. J., \& Whang, W. H. 2013. Cognitive Synergy in Multimedia Learning. International Education Studies, 6(4): 76-84.

Komalasari, K. 2019. Living Values Based Interactive Multimedia in Civic Education Learning. International Journal of Instruction, 12(1): 113-26.

Muhson, A. 2010. Pengembangan Media Pembelajaran Berbasis Teknologi Informasi. Jurnal Pendidikan Akuntansi Indonesia, 8(2): 1-10.

Mulyadi. R. \& Purnama, F. 2019. Pengembangan E-Learning Mata Pelajaran Teknologi Layanan Jaringan. Joisie, 3(2): 57-63.

Muslem, A. \& Abbas, M. 2017. The Effectiveness of Immersive Multimedia Learning with Peer Support on English Speaking and Reading Aloud. International Journal of Instruction 10(1): 203-18.

Nugroho, A. 2010. Rekayasa Perangkat Lunak Berorientasi Objek dengan Metode UDSP. Yogyakarta: Penerbit Andi.

Ranius, A. Y. 2013. Pemanfaatan E-Learning sebagai Media Pembelajaran. Jurnal Ilmiah Matrik, 15(1): 53-62.

Susanti, W. \& Ambiyar. 2018. Analisis Korespondensi Hubungan Strategi Pembelajaran dengan Hasil Belajar Mahasiswa. Seminastika, 1(2018): 20913. 